\title{
Selection of suitable passive cooling strategy for a subtropical climate
}

\author{
Ahmed-Shams Forruque Ahmed ${ }^{1 *}$, Khan-Mohammad Masud Kamal Khan ${ }^{1}$, Amanullah- Amanullah Maung Than Oo ${ }^{1,2}$ \\ and Rasul-Mohammad Golam Rasul ${ }^{1}$
}

\begin{abstract}
Background: Passive cooling system has become an attractive option to design and modify homes to achieve thermal comfort. The system provides cooling through the use of passive processes, which often use heat flow paths that do not exist in conventional or bioclimatic buildings.

Methods: Six different cities namely Rockhampton, Brisbane, Mackay, Townsville, Charleville and Mount Isa in the hot and humid subtropical climatic zone in Queensland, Australia have been considered for this study. Two main climatic factors such as the temperature and the relative humidity of those cities over a period of around 50 years have been taken into account in order to select the appropriate passive cooling strategy for a specific location.

Results: Results show that the passive cooling strategy of natural ventilation would be suitable for Rockhampton, Brisbane, Mackay and Townsville whereas high thermal mass would be appropriate for Mackay and Townsville.

Conclusion: The procedure of selecting an appropriate passive cooling strategy has been developed for the residences and buildings in a hot and humid subtropical climate. It would be applicable for all buildings with internal heat gains of a hot and humid subtropical climate and will encourage the inhabitants to design the building considering their local climatic conditions.
\end{abstract}

Keywords: Passive cooling strategy; Subtropical climate; Temperature; Relative humidity

\section{Background}

Reduction of energy consumption in buildings can be achieved by simple methods and techniques using an appropriate building design and energy-efficient system and technology, such as passive cooling system. The passive air cooling system provides cooling through the use of passive process without using customary mechanical units such as fan, compressor, etc. in regions where cooling is a dominant problem. Passive cooling strategy maximises the efficiency of the building envelope by minimising heat gain from the external sources and assisting heat loss to the natural sources of cooling such as air movement, cooling breezes, evaporation and earth coupling. The principle of passive cooling is to prevent heat from getting into a building during a warm day and bringing in cool air from outside when the temperature

\footnotetext{
* Correspondence: s.f.ahmed@cqu.edu.au

${ }^{1}$ School of Engineering and Technology, Central Queensland University,

Rockhampton Campus, Queensland 4702, Australia

Full list of author information is available at the end of the article
}

drops. Buildings consume a lot of energy, and the building sector is responsible for almost $40 \%$ of the total energy consumption on a national level, where the Australian buildings use up to one-third of their electricity on air conditioning (Cooling demand management 2014). The average energy consumption per person increased 10\% from 1990 to 2008, where the world population increased 27\% (Pérez-Lombard et al. 2008). During this period, the use of regional energy increased in the Middle East by $170 \%$, in China by $146 \%$, in India by $91 \%$, in Africa by $70 \%$, in Latin America by $66 \%$, in the USA by $20 \%$, in the EU-27 block by $7 \%$ and in the world overall by $39 \%$. World energy consumption will grow by $56 \%$ between 2010 and 2040. Total world energy use rises from 524 quadrillion British thermal units (Btu) in 2010 to 630 quadrillion Btu in 2020 and to 820 quadrillion Btu in 2040 (IEO, 2013). The net energy consumption of Australia increased at an average annual rate of $1.8 \%$ over 10 years from 1999-2000 to 2009-2010 (Cooling demand management 2014). The net energy consumption has 
increased by $1.1 \%(5,945$ petajoules (PJ)) compared to the previous 10 years. According to the Department of Climate Change and Energy Efficiency (Australia), the Australian residential sector energy consumption in 1990 was about 299 PJ (electricity, gas, LPG and wood) and that by 2008 had grown to about $402 \mathrm{PJ}$ and is projected to increase to 467 PJ by 2020 under the current trends. This represents a $56 \%$ increase of energy consumption in residential sector over the period 1990 to 2020 .

To reduce energy consumption, passive air cooling strategy is seen as a suitable option for all subtropical zones with both high humid summer and warm winter and subtropical zones with warm humid summer and mild winter. Two case studies for residential apartment buildings of Tehran, Iran and Swansea, UK, were discussed, and the cooling strategies were explored which could be adopted to reduce energy usage and the associated greenhouse gas emissions (Nooraei et al. 2013). A bioclimatic chart was developed for passive cooling strategies namely natural ventilation, evaporative cooling, high thermal mass and high thermal mass with night ventilation (DeKay and Brown 2013). The bioclimatic chart suggests different passive cooling strategies for different months in a year. All these passive cooling strategies depend on the daily changes in temperature and relative humidity. Among these strategies, the influence of thermal mass with night ventilation on the maximum indoor temperature was calculated for summer of hot humid climate of Israel (Shaviv et al. 2001).

Passive cooling strategies of evaporative cooling, natural ventilation, ground cooling and radiant cooling were discussed by Santamouris (2007). Three passive cooling strategies were tested for shading and non-shading system to determine their applicability in warm climates (La Roche and Milne 2004). Thermal performance of a passive cooling system of earth pipe cooling was investigated experimentally and numerically for a subtropical climate in Queensland, Australia (Ahmed et al. 2013, 2014a, b). To reduce energy consumption, an air-cooled chiller system in an office building was analysed using passive cooling (Chowdhury et al. 2009). The use of advanced passive cooling was explored in the context of complex non-domestic buildings (Rajapaksha and Hyde 2012). This study evaluated the present barriers and opportunities associated with the challenges of passive cooling through monitoring of an innovative case study of a building in southeast Queensland in Australia. The feasibility of passive cooling in newly built office buildings in the temperate climate of Belgium was assessed using standardised adaptive comfort criteria (Parys et al. 2012). In this research, two passive cooling schemes were studied: diurnal manual window operation and the combination of diurnal manual window operation and passive night ventilation.
Application of two passive cooling systems in a hot and humid climate in Rome was discovered to sustain the room temperature of the test cell to be lower than the ambient air by $2.0^{\circ} \mathrm{C}$ to $6.2^{\circ} \mathrm{C}$ and lower than the controlled cell by $1.4^{\circ} \mathrm{C}$ to $3.0^{\circ} \mathrm{C}$ (Calderaro and Agnoli 2007). A study was investigated how air temperature in rooms of a residential building is affected by some natural ventilation strategies in a hot dry climate (Idowu 2011). This study found that the variation in wind direction and the location of spaces have significant effect on cooling. Recommendations on the selection of appropriate ventilation strategies in relation to the prevailing external conditions were derived and the appropriateness of the control methods was discussed (Kolokotroni et al. 2001). Specific passive cooling strategies were identified over a part of the Sahara desert of Libya (Agrawal 1992). The potential of passive cooling techniques was discussed for Malaysian modern houses with the aim of reducing air-conditioning usage. A full-scale field experiment was carried out in this study to reveal the detailed indoor thermal environment for various ventilation strategies (Kubota and Chyee 2010). Persson and Westermark (2011) studied energy-efficient specific cooling strategies for a comfortable indoor climate in summer for Swedish climate.

The performance of different mixed-mode cooling strategies for a single-zone office space in four main arid cities representing diverse arid climates was evaluated, and the most effective strategies were considered for each city (Ezzeldin et al. 2009). The new concept of incorporating phase change materials (PCM) inside the building material for enhancing the room air quality and reducing the energy consumption consumed by the air conditionings in the buildings was examined (Madhumathi 2012). The experimental results showed an improvement of thermal comfort and reduction of energy consumption of the building containing PCM without substantial increase in the weight of the construction materials. A research was conducted to evaluate the performance of the existing materials integrated with PCM and to propose a passive design strategy that would improve the system (Isa et al. 2010). This research suggested copper foam as a medium to be integrated with microencapsulated PCM. The relationship between the building design and the natural ventilation was examined by Kleiven (2003). A concept to take ventilation air into the building from the top and to draw it down into the spaces below was examined using the stack effect associated with the difference in temperature between the internal and external environments. Methods of occasionally cooling the vertical intake ducts of passively ventilated buildings, adopting the top-down system both to boost airflows were also discussed (Gage et al. 2001). The effect of most important parameters affecting night ventilation performance such as building construction, heat gains, air change rates, heat transfer 
coefficients and climatic conditions was evaluated including annual variations on the number of overheating degree hours (operative room temperature $>26^{\circ} \mathrm{C}$ ) (Artmann et al. 2008). A bioclimatic chart was developed for Muscat, Oman which suggested some passive cooling strategies for different months in a year (Al-Azri et al. 2013). Most of these studies concentrated on more than one passive cooling strategies selection for different months in a year for hot and humid subtropical climate, which are not cost effective and difficult to implement. Therefore, it is necessary to find a procedure to select a suitable passive cooling strategy for a particular hot and humid climatic location which will assist to install only a specific passive cooling method for the entire life of the building. In view of these, the main aim of this study is to find a procedure to identify that cooling strategy for any hot and humid subtropical climate.

\section{Passive cooling strategies}

Passive cooling involves designing buildings for cooling load avoidance (Natural ventilation: cross ventilation 2014). Design strategies that minimise the need for mechanical cooling systems include proper window selection and orientation and day lighting design, selection of appropriate varnishing for windows and skylights, proper shading of glass when heat gains are not desired, use of light-coloured materials for the building envelope and roof, careful sitting and orientation decisions and good landscaping design. Buildings should be designed in relation to specific climatic conditions, the changed function or the time of use or occupancy levels of internal and external spaces, and in relation to how these results will impact the parts that remain unchanged. A passive cooling system is capable of transferring heat from a building to various natural heat sinks (Givoni 1994).

Passive air cooling is the least expensive means of cooling a room with the lowest environmental impact. The system uses elements of the building to store and distribute energy and when prevailing conditions are favourable to discharge heat to the cooler parts of the environment like the sky, atmosphere and ground. The passive cooling strategies eliminate mechanical air conditioning requirements such as fan, compressor, etc. in the modern buildings where cooling is a dominant requirement. Thus, the passive cooling is considered an alternative to mechanical cooling that requires complicated refrigeration systems. Four major common strategies are discussed below.

\section{Natural ventilation}

There are two major techniques in natural ventilation systems: cross ventilation and single-sided ventilation. Cross ventilation is attained when rooms with a double orientation with at least two walls face externally in opposite directions as shown in Figure 1a, and single ventilation is achieved when there is only one external facade as shown in Figure 1b. In the cross ventilation system, the action of any wind will then generate pressure differences between those openings and so will promote a robust airflow through an internal space. But in the single ventilation system, wind-driven ventilation flow is dominated by the turbulence of the wind, as caused by temporal changes in wind speed and direction. Hence, the cross ventilation is the design type of choice.

The benefits of using natural ventilation are $40 \%$ lower energy cost than the air-conditioned equivalents, capital costs savings in the region of $10 \%$ to $15 \%$, increased fresh air supply to a space which may result in higher thermal comfort levels and increased productivity and so on. Furthermore, all the typical cost indicators such as installation cost, capital and maintenance are low.

\section{Evaporative cooling}

A method of converting hot air into a cool breeze using the process of evaporating water is the evaporative cooling. By evaporating water, energy is taken from the air and the temperature is reduced. The natural process of water evaporation along with an air-moving system is utilised by evaporative coolers to generate effective cooling. Two temperatures are vital when dealing with evaporative cooling systems such as dry bulb temperature and wet bulb temperature. If the dry bulb temperature and wet bulb temperature are $35^{\circ} \mathrm{C}$ and $15^{\circ} \mathrm{C}$, respectively, the maximum drop in temperature due to evaporative cooling would theoretically be $20^{\circ} \mathrm{C}$. The cooling effect due to perspiration on the human skin is an example of evaporative cooling. In hot and humid climates, the cooling effect is less because of the high moisture content of the surrounding air. The four major factors
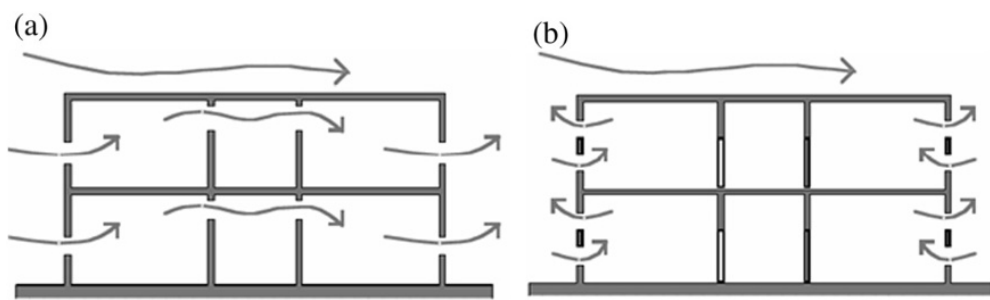

Figure 1 Natural ventilation strategy (Natural ventilation: cross ventilation 2014). (a) Cross ventilation. (b) Single-sided ventilation. 
(a)

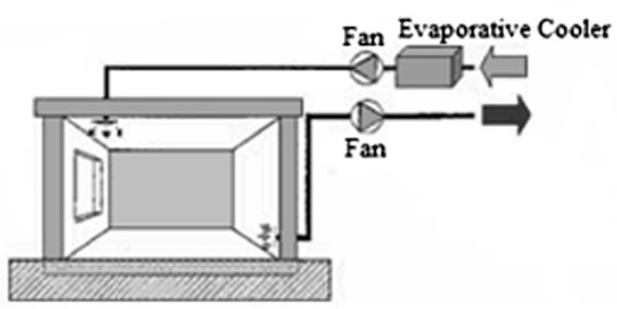

(b)

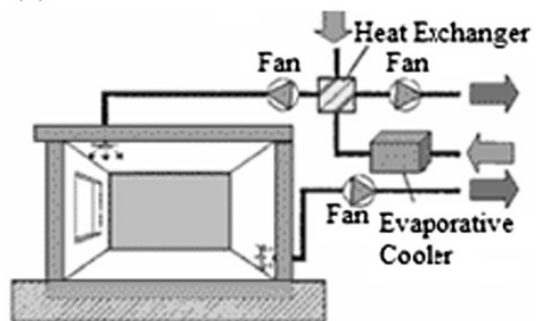

Figure 2 Evaporative cooling strategy (Alternatives to active HVAC systems 2012). (a) Direct evaporative cooling. (b). Indirect evaporative cooling.

that affect the rate of evaporation are relative humidity, air temperatures, air movement and surface area. There are two general methods of evaporative cooling: direct and indirect.

Direct evaporative cooling involves the movement of air past a water spray (air washer/water spraying chamber) or other wetted medium (evaporative pads, rigid media or evaporating wheel) as shown in Figure 2a. The energy performances of direct evaporative cooler are $250 \mathrm{~W}$ per $3,600 \mathrm{~m}^{3} / \mathrm{h}$ for typical electric fan power and 60 to $100 \mathrm{~W}$ for electricity consumption for the pump (Patel 2011). Investment costs are a bit higher than those for standard (vapour compression) air conditioning systems: A direct evaporative cooler costs about one third $(1 / 3)$, a two-stage evaporative cooler about two thirds $(2 / 3)$ more than comparable mechanical cooling equipment. Indirect evaporative cooling systems attempt to solve the problem of the high level of humidity that is produced by direct evaporative cooling with the help of a secondary heat exchanger as shown in Figure 2. Indirect evaporative coolers can operate only if the indoor wet bulb temperature is lower than the outdoor dry bulb temperature. In extremely dry climates, evaporative cooling of air has the added benefit of conditioning the air with more moisture for the comfort of building occupants. Lower energy consumption and lower $\mathrm{CO}_{2}$ emission and indoor air quality may be improved due to higher outside air which are the main benefits of using evaporative cooling. Evaporative cooling can save up to $80 \%$ of the energy used by a refrigerated air conditioner. The typical cost indicators such as installation cost, capital and maintenance are low in evaporative cooling.

\section{High thermal mass}

A high thermal mass structure has the ability to absorb and store heat during the day as shown in Figure 3a and save it for night as shown in Figure 3b. When thermal mass is exposed to the interior, it absorbs heat from internal sources and dampens the amplitude of the interior temperature swing. All matter has thermal mass; however when used in reference to a building, thermal mass generally means materials capable of absorbing, holding and gradually releasing heat. Heavy, dense building materials with high specific heat like concrete, brick and other masonry have high thermal mass. Thermally massive materials absorb heat and slowly release it when there is a temperature difference between the mass and the surrounding space.

By this process, internal temperatures can be held significantly below external ambient temperatures during the summer. Equally, in winter, mass can absorb heat gained which builds up during the day and releases it into the space at night. This can potentially reduce (a)

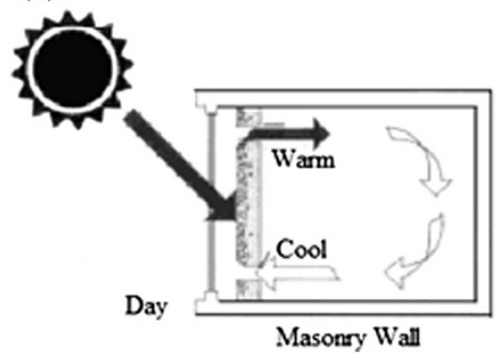

(b)

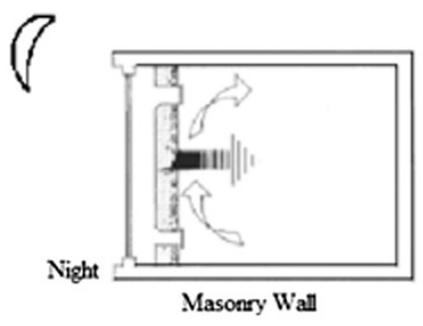

Figure 3 High thermal mass strategy (Sustainable construction with concrete: Trombe walls, Residential Concrete 2007). (a) High thermal mass during day. (b) High thermal mass during night. 
heating demand. Appreciable reduction of the indoor temperature can be achieved in such buildings, with indoor air maxima about $3^{\circ} \mathrm{C}$ below outdoor air maxima having been observed in some cases (Givoni 1994). The main advantages of using high thermal mass are reduced annual energy use, reduced peak demand, a more stable internal environment, increased acoustic insulation of assemblies and improved fire ratings of assemblies. The installation cost, capital and maintenance cost are low to install this passive cooling system.

\section{High thermal mass with night ventilation}

Night ventilation is the use of the cold night air to cool down the structure of a building so that it can absorb heat gains during the daytime reducing the daytime temperature rise. Night ventilation is an overheating prevention strategy which uses little or no fossil energy. The success of this strategy is however highly dependent on large diurnal temperature differences. Heat is normally absorbed and stored during the day by building structure elements, and it is released back into spaces in the second half of the day. Warm air would build up by heat gain from interior surfaces during the night and hence increases air temperatures the next day. As a result, night ventilation is needed to flush the heat out. To optimise the daytime cooling capacity of thermal mass, the mass should be ventilated at night to allow relatively cool night air to remove heat absorbed in the mass during the day as shown in Figure 4. A reduction in the indoor temperature of about $3^{\circ} \mathrm{C}$ to $6^{\circ} \mathrm{C}$ below the exterior air may be achievable, depending on the local climate, the amount of mass, its distribution and the ventilation details. Night ventilation in this case can utilise the fluctuation in air temperatures to cool the building envelope and bring fresh air into building spaces.

If the windows are open during the night and early hours of the morning, the building would be cooled and the heat would be eliminated. Night ventilation may be used from 00:00 to 9:00 a.m. during the overheated periods of the year. It may not, however, be without initial costs, since the requirement for ducts and controls may represent an additional cost.

\section{Thermal comfort analysis}

Thermal comfort is the condition of mind which expresses satisfaction with the thermal environment (Fanger 1970). In other words, an individual who is experiencing thermal comfort is the one who is satisfied and feels thermally comfortable with his surrounding environment. Four indoor environmental factors such as air temperature, air humidity, air velocity and surface temperatures affect the thermal comfort. Each factor affects thermal comfort differently. The factors most commonly addressed in the conventional design process - air temperature and air humidity - in fact affect only $6 \%$ and $18 \%$ of our perception of thermal comfort, respectively. To take a more effective comfort-focused approach, temperature of surrounding surfaces and air velocity must be considered, which account for $50 \%$ and $26 \%$ of thermal comfort perception, respectively. There are three main reasons behind the study of thermal comfort, which is to achieve user satisfaction, efficient energy consumption and to set a standard with a range of thermal comfort temperature for a particular environment. In 2004, ASHRAE Standard 55 has a lower margin of relative humidity that expands the comfort temperature. When the relative humidity is as low as $10 \%$, the suggested comfort range is from $25^{\circ} \mathrm{C}$ to $28^{\circ} \mathrm{C}$, while when the relative humidity is $55 \%$, the suggested comfort range is from $24^{\circ} \mathrm{C}$ to $27^{\circ} \mathrm{C}$ (Standard 2004). Various researches have been carried out in search of the correct thermal comfort range for hot and humid climate such as the Australian climate. These researches investigated on occupants living in naturally ventilated, air-conditioned or mixed both naturally ventilated and air-conditioned buildings.

From the previous researches of the indoor thermal comfort range and neutral temperature under hot and humid climate, it has seen that the researches for naturally ventilated buildings were carried out from 1952 to 2009 and for air-conditioned or mixed both naturally ventilated and air-conditioned buildings were carried out from 1990 to 2009. The findings on the occupants living in naturally ventilated buildings have shown that the neutral temperature, $T_{\mathrm{n}}$ ranges from $26.1^{\circ} \mathrm{C}$ to $28.9^{\circ} \mathrm{C}$ and the average $T_{\mathrm{n}}$ is $28.1^{\circ} \mathrm{C}$. Meanwhile, the thermal comfort temperature ranges from $22.7^{\circ} \mathrm{C}$ to $33.0^{\circ} \mathrm{C}$ and the average
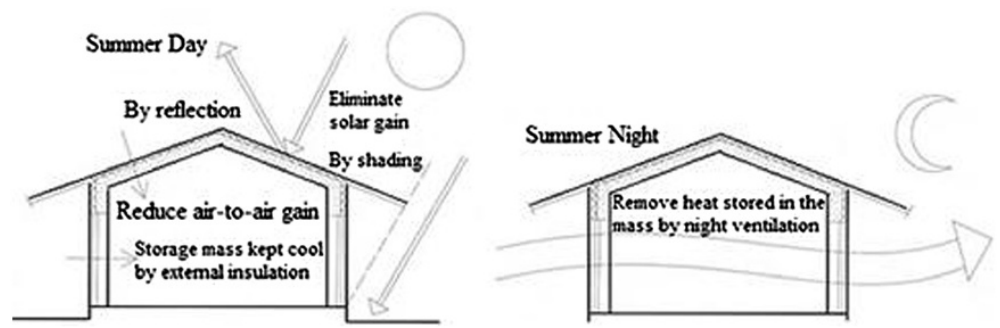

Figure 4 High thermal mass with night ventilation strategy (Natural ventilation: cross ventilation 2014). 
upper limit of the thermal comfort temperature is $30.3^{\circ} \mathrm{C}$. The findings on the occupants living in air-conditioned or mixed both naturally ventilated and air-conditioned buildings have shown that the neutral temperature, $T_{\mathrm{n}}$ ranges from $24.2^{\circ} \mathrm{C}$ to $27.5^{\circ} \mathrm{C}$ and the average $T_{\mathrm{n}}$ is $25.9^{\circ} \mathrm{C}$. Meanwhile, the thermal comfort temperature ranges from $20.8^{\circ}$ $\mathrm{C}$ to $29.5^{\circ} \mathrm{C}$ and the average upper limit of the thermal comfort temperature is $28.3^{\circ} \mathrm{C}$. The overall findings for naturally ventilated, air-conditioned or mixed both naturally ventilated and air-conditioned buildings have shown that the occupants living in air-conditioned building have less tolerance to high dry bulb temperature as compared to occupants living in naturally ventilated building. This is the reason for lower neutral temperature, $T_{\mathrm{n}}$, and thermal comfort temperature range in fully and partially airconditioned building.

\section{Methods}

The selection of an appropriate passive cooling strategy for a building of a particular location is based heavily on the local climatic condition of that location. Identification of an appropriate strategy for a particular location depends on two major climatic factors such as air temperature and relative humidity. Therefore, it is necessary to analyse the climatic conditions of the particular location to find an appropriate passive cooling strategy for that location.

\section{Climatic analysis}

Climate change is recognised as one of the major challenges facing Australia and the world today. The energy consumption in the residential sector is a significant contributor to Australian stationary energy greenhouse gas emissions. Increased energy consumption due to higher temperatures and adverse health effects on building occupants caused by overheating due to higher temperatures are the main impacts of climate change for Australian buildings. Annual average daily mean temperatures over the land of Australia showed little change from 1910 to 1950, but have progressively warmed since, increasing by $0.9^{\circ} \mathrm{C}$ from 1910 to 2011 (State Of The Climate 2012). Since 1951, mean temperatures have increased $0.1^{\circ} \mathrm{C}$ to $0.2^{\circ} \mathrm{C}$ per decade over most of Australia, with the greatest warming occurring inland, particularly in Queensland and the southern half of Western Australia, although some cooling has occurred in southern Queensland and New South Wales (Hughes 2003). By 2030, annual average temperatures are projected to be $0.4^{\circ} \mathrm{C}$ to $2.0^{\circ} \mathrm{C}$ higher over most of Australia (relative to 1990), with slightly less warming in some coastal areas and the potential for greater warming in the north-west. By 2070, annual average temperatures may increase by $1.0^{\circ} \mathrm{C}$ to $6.0^{\circ} \mathrm{C}$ (Australian Building Codes Board (ABCB) 2010). Small decreases in relative humidity are projected over most of
Australia. The range of change in annual humidity by 2030 is around $-2 \%$ to $+0.5 \%$ with a best estimate of around a $1 \%$ decline. The projected changes are larger for 2050 and 2070, particularly under the higher emission scenarios (Sreshthaputra et al. 2004).

Average maximum and minimum temperature in centigrade scale and average maximum and minimum relative humidity in percentage were taken to identify the climatic condition of six cities, namely Rockhampton, Brisbane, Mackay, Townsville, Charleville and Mount Isa of subtropical zone Queensland, Australia. Data were collected from the Bureau of Meteorology, Australia, to plot the lines for each month of a period of around 50 years. The plotted lines shown in Figure 5 represent the change in temperature and relative humidity of a certain city over an average day. The Figure 5 also shows the fluctuation of temperature and relative humidity in the six cities of Queensland. There are three major sources of this unexpected heat such as direct solar impacts on a building and through windows and skylights, heat transfer and infiltration of exterior high temperatures through the materials and elements of the structure and the internal heat produced by appliances, equipment and inhabitants. In these cases, passive cooling systems are a good strategy based on the interaction of the building and its surroundings to reduce heat from internal spaces with heat loads for hot and humid climate like Queensland and it is also important in the context of comfort. We can design a building by forming a chart that would be able to suggest the most efficient passive cooling strategy based on the particular climatic location of the building.

\section{Bioclimatic chart and selection procedure}

Bioclimatic chart is a preliminary analysis tool used during the early planning stages of a building project. It has the purpose of identifying desirable adaptations of structure to meet human comfort needs under specific climatological conditions. That is, the bioclimatic chart would indicate a comfort zone where no cooling or heating is required to maintain thermal comfort. Using the chart, simple building techniques and methods such as incorporating natural cooling systems and techniques, passive solar heating system as well as natural lighting systems and techniques can be applied to the buildings to reduce energy consumption.

The chart making procedure is also very essential for the design and analysis of heating, ventilation and air conditioning (HVAC) systems. In order to create a bioclimatic chart, monthly statistical data are collected. Bioclimatic chart is created by plotting two points for each month. The first plotting point is used to indicate the minimum temperature and maximum relative humidity. The second plotting point is used to indicate maximum temperature and minimum relative humidity. The 


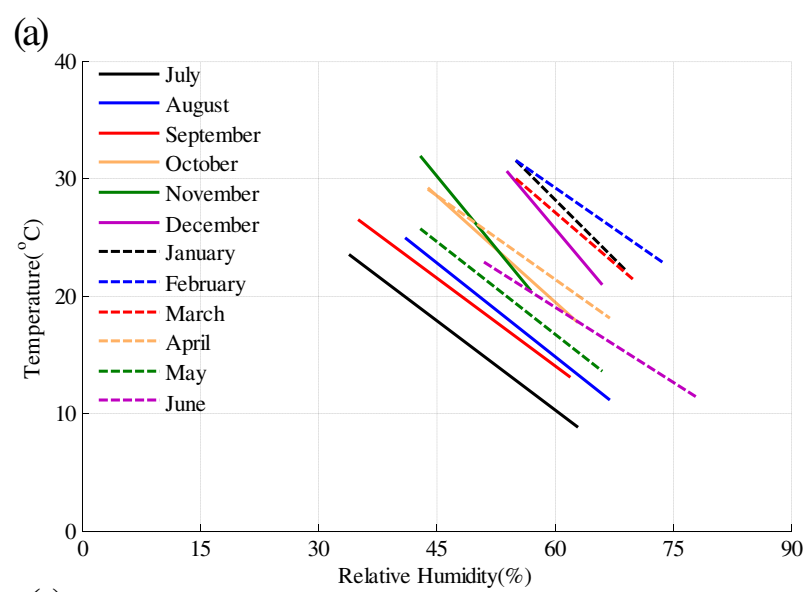

(c)

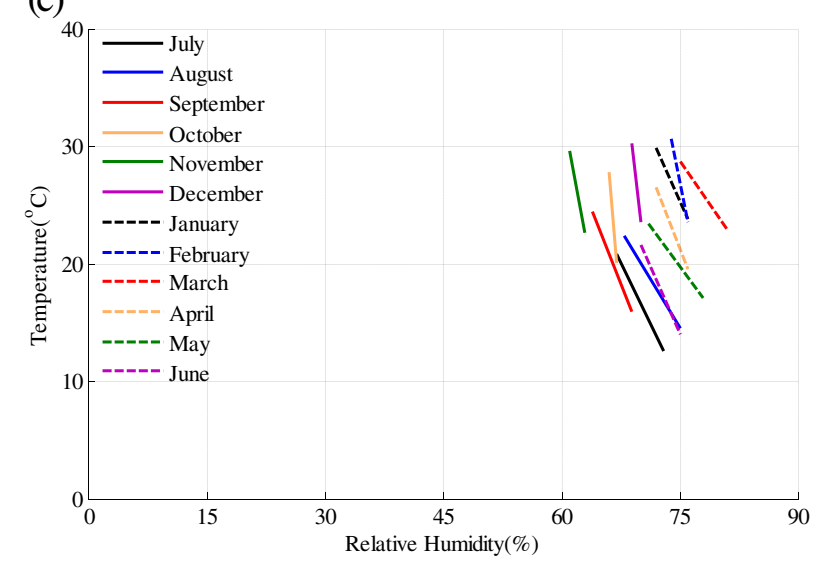

(e)

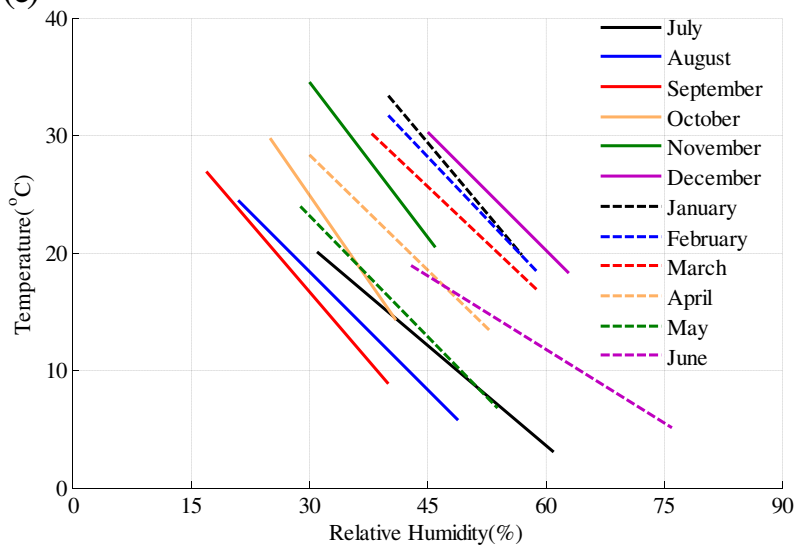

(b)

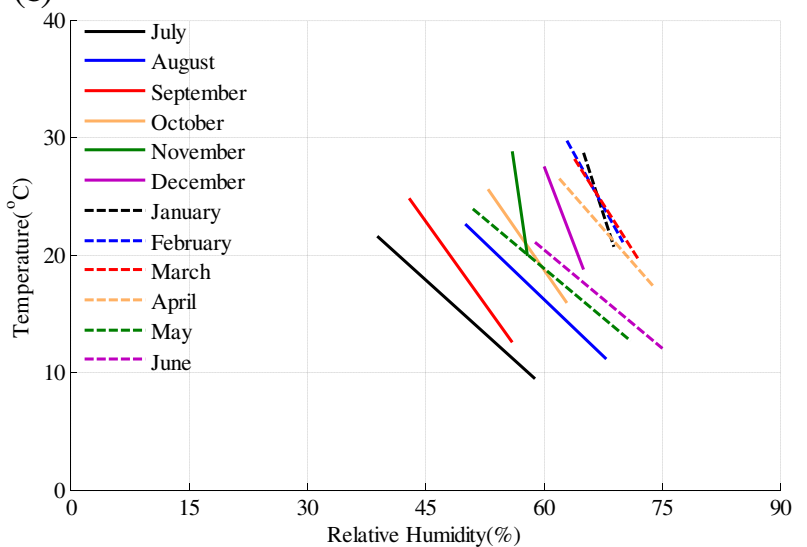

(d)

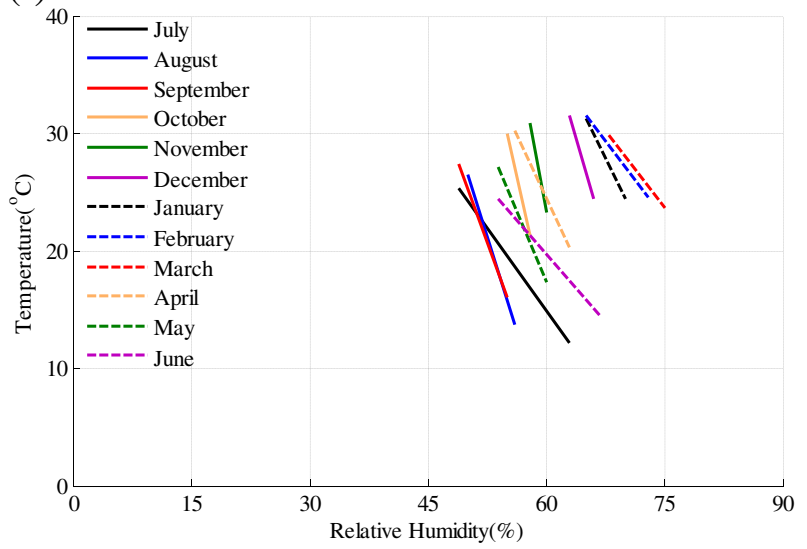

(f)

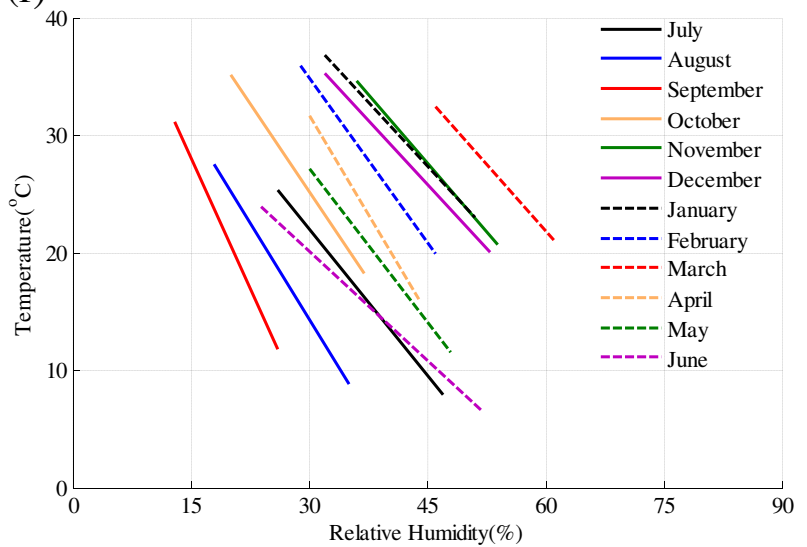

Figure 5 Change in temperature and relative humidity in Queensland. (a) Rockhampton. (b) Brisbane. (c) Mackay. (d) Townsville. (e) Charleville. (f) Mount Isa.

bioclimatic chart indicates the boundaries for different types of passive design strategies. A bioclimatic chart has been developed in this study for subtropical climatic zones in Queensland, Australia, and is discussed in this section.

Givoni developed a chart for identifying suitable passive cooling strategy as shown in Figure 6a (Givoni 1994;
Givoni 1992). The chart is based on the linear relationship between the temperature amplitude and vapour pressure of the outdoor air. The chart was developed by first identifying the average monthly climatic condition. For each month, the average of the daily maximum temperature was calculated and matched with the average of the minimum daily absolute humidity to form a point. Another 


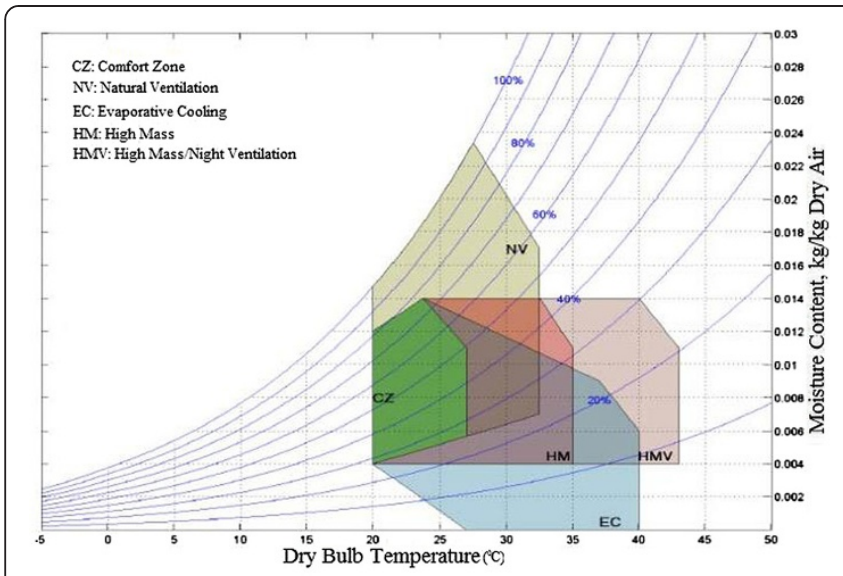

(a)

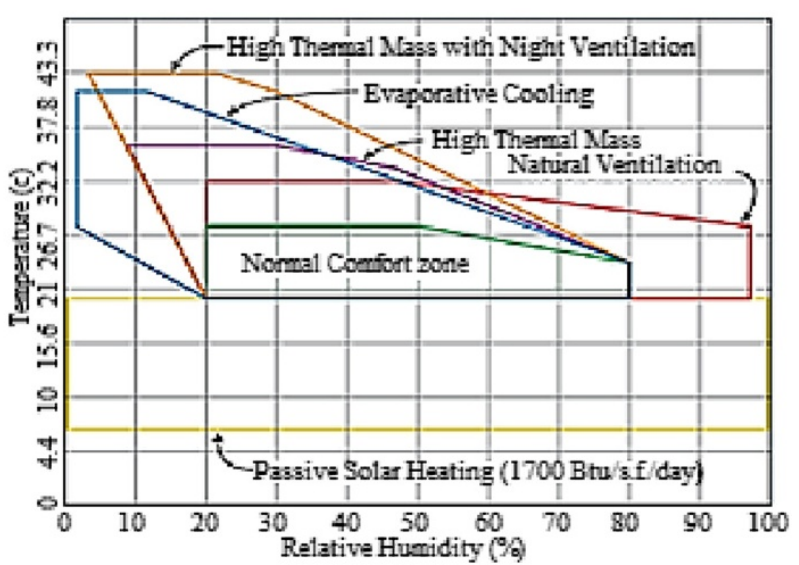

(b)

Figure 6 Bioclimatic charts for passive cooling strategies. (a) Givoni's chart. (b) Brown's chart.

chart based on temperature and relative humidity was developed to select suitable passive cooling strategy as shown in Figure 6b. This chart has been considered as the standard to compare with the chart developed in this study. In Figure $6 \mathrm{~b}$, the temperature has been converted from Fahrenheit to centigrade scale in case of comparison with other charts.

The passive cooling strategies used in the chart depend on daily changes in temperature and relative humidity. Both the charts are suitable for residences and other buildings with internal heat gains. The chart identifies the appropriate passive cooling strategy of a particular subtropical climatic location using the plotted lines for each month in a year. The lines were plotted by taking average maximum and minimum temperature and average maximum and minimum relative humidity. In those cases, two or more passive cooling strategies have to be installed for the inhabitants to design the building for their climatic location for different months in a year.

To minimise the cost, it is necessary to develop a chart that would be suitable to select only one passive cooling strategy for a particular subtropical climatic zone. Based on two climatic factors temperature and relative humidity, a chart has been formed for selecting an appropriate passive cooling strategy for the entire life of buildings of a particular region of hot and humid subtropical climate, Queensland, Australia. Six cities of Queensland, namely, Rockhampton, Brisbane, Mackay, Townsville, Charleville and Mount Isa were considered for the chart as shown in Figure 7. To produce the chart, current climatic condition of these regions was analysed by taking average maximum and minimum temperature and average

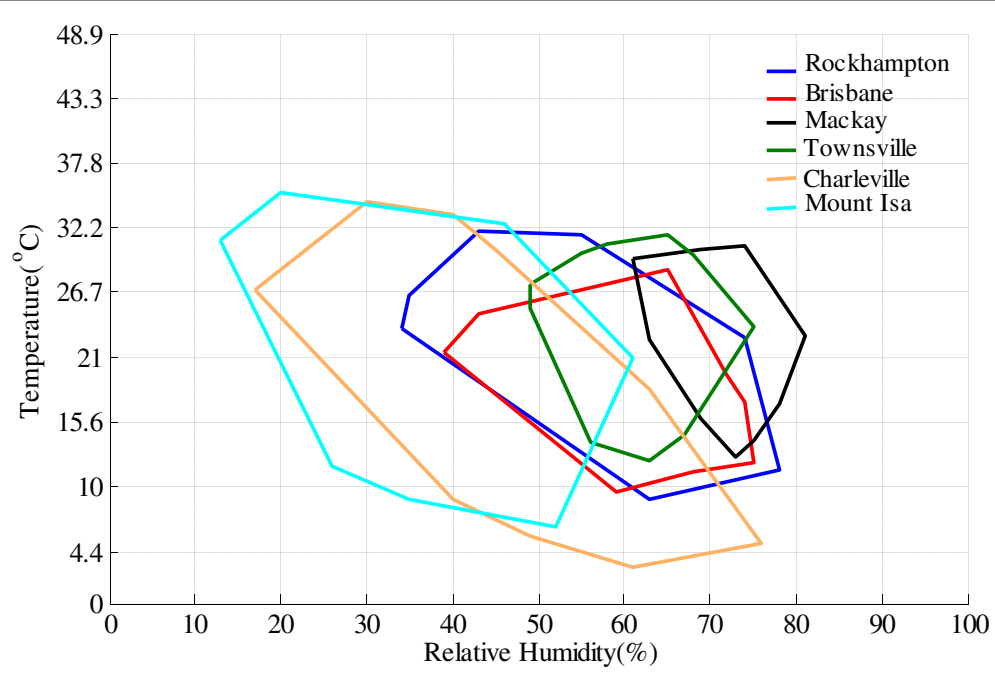

Figure 7 Temperature humidity zone for Queensland, Australia. 


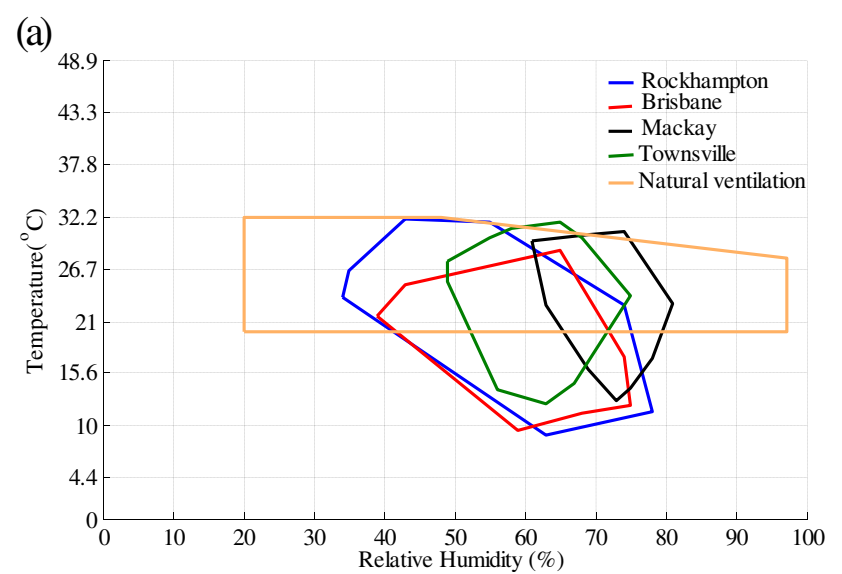

(b)

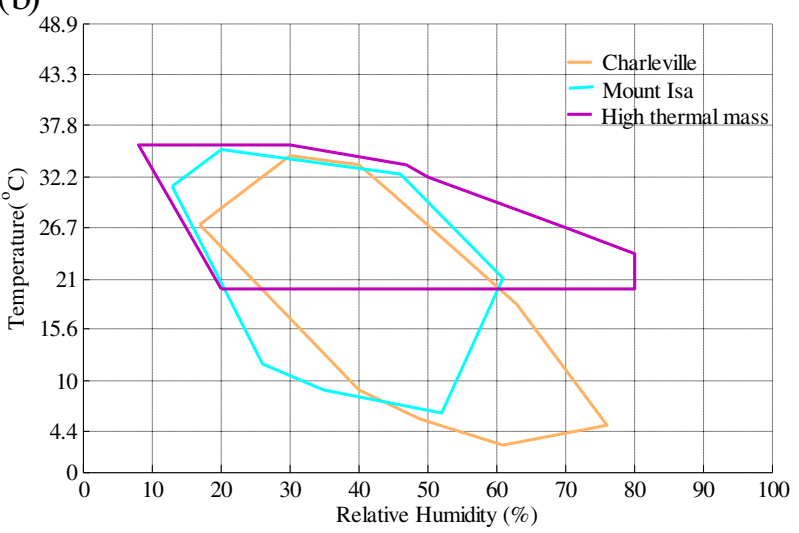

Figure 8 Selection of passive cooling strategies. (a) Natural ventilation strategy selection. (b) High thermal mass strategy selection.

maximum and minimum temperature of each month over a long period, for example, Rockhampton (1939 to 2012), Brisbane (1949 to 2000), Mackay (1959 to 2012), Townsville (1940 to 2012), Charleville (1942 to 2012) and Mount Isa (1966 to 2012).

To find the maximum temperature-humidity zone of the cities, six curves were drawn for six cities by taking the most exterior points of the plotted lines in the change in temperature and relative humidity as shown in Figure 7. The zones plotted in the chart have been compared with the zones of Brown's chart to identify the appropriate cooling strategy for the buildings of each city.

\section{Results and discussion}

Appropriate passive cooling strategy selection for a building is mainly used to design early planning stages to define potential building design strategies to achieve indoor thermal comfort. The procedure for selecting specific passive cooling strategy can be used to design buildings that include the most energy-efficient strategy based on the climate and location of a building site.

The plotted zones for Rockhampton, Brisbane, Mackay and Townsville are close to the natural ventilation zone as shown in Figure 8a indicating that the natural ventilation would be applied to these locations as the appropriate passive cooling strategy. Also, the temperature swings between day and nights are not trivial in Rockhampton, Brisbane, Mackay and Townsville as shown in Figure 5a,b, $\mathrm{c}, \mathrm{d}$ so that natural ventilation would be most suitable in such hot and humid climatic zones. The Charleville and Mount Isa zones shown in Figure 8b are close to the zone of high thermal mass so the high thermal mass would be the appropriate passive cooling strategy for those regions. The results based on the new chart shown in Figure 7 are valid as the results have been obtained by comparing it with the standard valid chart shown in Figure 6b.
If a zone were close to two and more zones of Figure 6b, one or two strategies would be chosen from these strategies that are compatible with each other and the building design. This selection procedure for suitable passive cooling strategy will assist the homeowners to install the most suitable passive cooling strategy for the entire life of their building in any hot and humid subtropical climatic location. They will be benefited financially as there is no need to install more than one passive cooling strategy. The use of suitable passive cooling strategy is a great advantage with the raising concerns regarding the cost and environmental impact of energy use. It focuses on heat gain control and heat dissipation in a building in order to improve the indoor thermal comfort. Furthermore, it can greatly reduce the energy consumption, for example, the natural ventilation assists to save energy cost of $40 \%$ lower than the air-conditioned equivalents (Bhatia 2012).

\section{Conclusions}

Passive design strategy is an approach to building design that uses the building architecture to minimise energy consumption and improve thermal comfort. Thermal comfort refers to our thermal perception of our surroundings. Two major environmental factors such as air temperature and relative humidity affect the thermal comfort directly. These two factors have been taken to identify the climatic condition of the six cities of Queensland, Australia. Through investigating the local climatic conditions, a chart for six cities of Queensland was developed to identify suitable passive cooling strategies for the buildings with internal heat gains of a specific climatic location by comparing with a standard chart shown in Figure 6b. The procedure of the formation of the chart would be applicable for all buildings with internal heat gains of a hot and humid subtropical climate and will encourage the inhabitants to design the building considering their local climatic conditions. The building energy requirements can 
be greatly reduced by adopting the passive design principles. For minimising cooling need, some of the key strategies may also apply to the buildings by involving appropriate orientation and spatial organisation, shading and appropriate use of materials, colours, textures and vegetation.

\section{Competing interests}

The authors declare that they have no competing interests.

\section{Authors' contributions}

SF Ahmed (First author) has done the work and manuscript writing. MMK Khan (Second author) discussed with the first author to develop a bioclimatic chart. Second, third and 4th author contributed to and/or helped in the manuscript write up and concept through direct input of idea or revision.

\section{Authors' information}

S.F. Ahmed is doing a Ph.D. research on passive air cooling in the school of Engineering and Technology at Central Queensland University, Australia. He received his M.Phil. degree from the University of Rajshahi, Bangladesh in 2011. His research interests are in the area of Applied Mathematics, Fluid Mechanics and Sustainable Energy Technologies. He has published over 15 research papers including a book. M.M.K. Khan is currently a Professor of Mechanical Engineering in the School of Engineering and Technology at Central Queensland University, Australia. He received his Ph.D. degree from the University of Sydney, Australia, in 1990. His research and teaching interests are in the area of Fluid Mechanics and Sustainable Energy Technologies. He has published over 210 research papers including 7 book chapters and has spent 3 visiting professorial positions in the US and Canada. He serves in the Editorial Board of two journals and is a member of the Institute of Engineers, Australia, and other professional bodies. M.T.O. Amanullah is currently a senior lecturer in Electrical Engineering in the School of Engineering at Deakin University, Australia. Aman research and research interest are in the area of Power Systems, Energy Efficiency, Renewable Energy and its enabling technologies. He has over 150 fully peer-reviewed papers and he is an invited editor of a number of Journals. M.G. Rasul obtained his Ph.D. from the University of Queensland, Australia. Currently, he is an Associate Professor in Mechanical Engineering, Central Queensland University, Australia. He is specialised and experienced in research and teaching in the areas of energy and thermodynamics. He has made significant contributions in research with over 280 publications and $\$ 2.5$ million research grants. He is involved with professional communities through his varied roles such as Membership of Engineers Australia, various conference committees, editorship and grant assessors.

\section{Author details}

${ }^{1}$ School of Engineering and Technology, Central Queensland University, Rockhampton Campus, Queensland 4702, Australia. ${ }^{2}$ School of Engineering, Deakin University, Geelong Waurn Ponds, Victoria 3216, Australia.

\section{Received: 25 February 2014 Accepted: 5 August 2014}

\section{Published online: 26 September 2014}

\section{References}

Agrawal, PC. (1992). Review of passive systems and passive strategies for natural heating and cooling of buildings in Libya. International Journal of Energy Research, 16(2), 101-117.

Ahmed, SF, Khan, MMK, Amanullah, MTO, Rasul, MG, \& Hassan, NMS (2013). Thermal performance analysis of earth pipe cooling system for subtropical climate. In 12th International Conference on Sustainable Energy Technologies, 1975-1803.

Ahmed, SF, Khan, MMK, Amanullah, MTO, Rasul, MG, \& Hassan, NMS (2014a). Performance analysis of vertical earth pipe cooling system for subtropical climate. In 13th International Conference on Clean Energy, 691-700.

Ahmed, SF, Khan, MMK, Amanullah, MTO, Rasul, MG, \& Hassan, NMS (2014b). Comparison of earth pipe cooling systems with two different piping systems. In International Conference on Applied Energy.

Al-Azri, N, Zurigatb, YH, \& Al-Rawahia, N. (2013). Selection and assessment of passive cooling techniques for residential buildings in Oman using a bioclimatic approach. The Journal of Engineering Research, 10(2), 53-65.
Alternatives to active HVAC systems (2012). http://www.cedengineering.com/ courseoutline.asp?cid=335. Accessed 20 February 2014 (2012).

Australian Building Codes Board (ABCB). (2010). An investigation of possible building code of Australia (BCA) adaptation measures for climate change, Canberra. Available at: http://www.google.com.au/url?sa=t\&rct=j\&q=\&esrc=s\& source $=$ web\&cd $=1 \& \mathrm{cad}=$ rja\&uact $=8 \&$ ved $=0$ CBOQFjAA\&url=http\%3A\%2F\% 2Fwww.abcb.gov.au\%2F \%2Fmedia\%2FFiles\%2FDownload\%2520Documents \%2FConsultation\%2F2010-12_Investigation_of_Possible_BCA_Adaptation_ Measures_for_Climate_Change_Final.ashx\&ei=j7QWN76MZDnuQSu9oGICQ\& usg=AFQjCNEhgZaYXFiYODZAfNVGmmYGheKsBg\&bvm=bv.75097201,d.dGc

Artmann, N, Manz, H, \& Heiselberg, P. (2008). Parameter study on performance of building cooling by night-time ventilation. Renewable Energy, 33(12), 2589-2598.

Bhatia, A (2012). Alternatives to Active HVAC Systems. [cited on 14 April 2014]; Available from: <http://www.cedengineering.com/upload/Alternatives\%20to \%20Active\%20HVAC\%20Systems.pdf>.

Calderaro, V, \& Agnoli, S. (2007). Passive heating and cooling strategies in an approach of retrofit in Rome. Energy and Buildings, 39(8), 875-885.

Chowdhury, AA, Rasul, MG, \& Khan, MMK. (2009). Modelling and analysis of aircooled reciprocating chiller and demand energy savings using passive cooling. Applied Thermal Engineering, 29(8), 1825-1830.

Cooling Demand management (2014). [cited on 15 April 2014]; Available from: <http://raee.org/climatisationsolaire/gb/cooling.php>.

DeKay, M, \& Brown, GZ (2013). Sun, wind, and light: architectural design strategies. Hoboken, NJ, United States of America: John Wiley \& Sons.

Ezzeldin, S, Rees, S, \& Cook, M (2009). Performance of mixed-mode cooling strategies for office buildings in arid climates. In Proceedings of the 11th International IBPSA Conference, Glasgow, Scotland.

Fanger, PO (1970). Thermal comfort: analysis and applications in environmental engineering.

Gage, SA, Hunt, GR, \& Linden, PF. (2001). Top down ventilation and cooling. Journal of Architectural and Planning Research, 18(4), 286-301.

Givoni, B. (1992). Comfort, climate analysis and building design guidelines. Energy and buildings, 18(1), 11-23.

Givoni, B (1994). Passive low energy cooling of buildings. Canada: John Willey \& Sons.

Hughes, L. (2003). Climate change and Australia: trends, projections and impacts. Austral Ecology, 28(4), 423-443.

Idowu, OM. (2011). Cooling effects of natural ventilation of a home in hot dry climate. International Journal on Architectural Science, 8, 114-121.

Isa, MHM, Zhao, X, \& Yoshino, H. (2010). Preliminary study of passive cooling strategy using a combination of PCM and copper foam to increase thermal heat storage in building facade. Sustainability, 2(8), 2365-2381.

Kleiven, T (2003). Natural ventilation in buildings: architectural concepts, consequences and possibilities (PhD Thesis). Norwegian University of Science and Technology, Norway.

Kolokotroni, M, Perera, MDAES, Azzi, D, \& Virk, GS. (2001). An investigation of passive ventilation cooling and control strategies for an educational building. Applied Thermal Engineering, 21(2), 183-199.

Kubota, T, \& Chyee, DTH. (2010). Potential of passive cooling techniques for modern houses in the tropical climate of Malaysia-analysis of the indoor thermal environment for various ventilation strategies. International Journal of Ventilation, 9(1), 11-24.

La Roche, P, \& Milne, M. (2004). Effects of window size and thermal mass on building comfort using an intelligent ventilation controller. Solar Energy, 77(4), 421-434.

Madhumathi, AA. (2012). Experimental study of passive cooling of building facade using phase change materials to increase thermal comfort in buildings in hot humid areas. International Journal of Energy \& Environment, 3(5), 739-748.

Natural ventilation: cross ventilation (2014). [cited on 14 April 2014]; Available from: <http://www.architecture.com/SustainabilityHub/Designstrategies/Air/12-1-3-naturalventilation-crossventilation.aspx>.

Nooraei, M, Littlewood, J, \& Evans, N (2013). Passive cooling strategies for multistorey residential buildings in Tehran, Iran and Swansea, UK. In Sustainability in Energy and Buildings (pp. 623-636). New York Dordrecht London: Springer Heidelberg.

Parys, W, Breesch, H, Hens, H, \& Saelens, D. (2012). Feasibility assessment of passive cooling for office buildings in a temperate climate through uncertainty analysis. Building and Environment, 56, 95-107.

Patel, M (2011). Heat and mass transfer solution. USA: McGraw-Hill Co.

Pérez-Lombard, L, Ortiz, J, \& Pout, C. (2008). A review on buildings energy consumption information. Energy and buildings, 40(3), 394-398. 
Persson, J, \& Westermark, M. (2011). Simulations of comfort cooling strategies in Passive Houses in a Swedish climate. In I Linköping Electronic Conference Proceedings, World Renewable Energy Congress (pp. 2072-2079).

Rajapaksha, U, \& Hyde, R. (2012). Barriers to and opportunities for advanced passive cooling in sub-tropical climates. Architectural Science Review, 55(1), 49-60.

Santamouris, M (2007). Advances in passive cooling. UK: Earthscan.

Shaviv, E, Yezioro, A, \& Capeluto, IG. (2001). Thermal mass and night ventilation as passive cooling design strategy. Renewable Energy, 24(3), 445-452.

Sreshthaputra, A, Haberl, J, \& Andrews, MJ. (2004). Improving building design and operation of a Thai Buddhist temple. Energy and buildings, 36(6), 481-494.

Standard, A (2004). Standard 55-2004. Thermal environmental conditions for human occupancy.

State Of The Climate (2012). Bureau of Meteorology. Australia: Australian Government - Bureau of Meteorology.

Sustainable construction with concrete: Trombe walls, Residential Concrete. (2007). http://www.concreteconstruction.net/construction/sustainableconstruction-with-concrete-trombe-wal.aspx. Accessed 20 February 2014 (2007).

doi:10.1186/s40712-014-0014-7

Cite this article as: Ahmed et al: Selection of suitable passive cooling strategy for a subtropical climate. International Journal of Mechanical and Materials Engineering 2014 9:14.

\section{Submit your manuscript to a SpringerOpen ${ }^{\circ}$ journal and benefit from:}

- Convenient online submission

- Rigorous peer review

- Immediate publication on acceptance

- Open access: articles freely available online

- High visibility within the field

- Retaining the copyright to your article

Submit your next manuscript at $\gg$ springeropen.com 